\title{
Bilateral renal angiomyolipoma presenting as tuberous sclerosis syndrome
}

\section{Gaurav Prakash, Satyanarayan Sankhwar, Ankur Jhanwar, Kawaljit Singh}

Department of Urology, King George's Medical University (KGMU), Lucknow, Uttar Pradesh, India

\section{Correspondence to}

Dr Gaurav Prakash,

gaurav.kgmc08@gmail.com

Accepted 26 February 2016

\section{DESCRIPTION}

A 30-year-old woman presented with generalised abdominal pain of 3-month duration. She had a history of epilepsy and low intelligence since childhood. On examination, she was found to have multiple painless papules on her face (figure 1) and periungual nodules involving all the toes (figure 2). CT of the abdomen suggested large bilateral angiomyolipoma of the kidney (figure 3). Assuming it to be a case of tuberous sclerosis complex, her neurological, dental and cardiology evaluations were carried out and found to be normal. After explaining the disease and prognosis, she was managed conservatively and advised to be under regular follow-up.

Bourneville or tuberous sclerosis syndrome is an autosomal dominant entity with the incidence

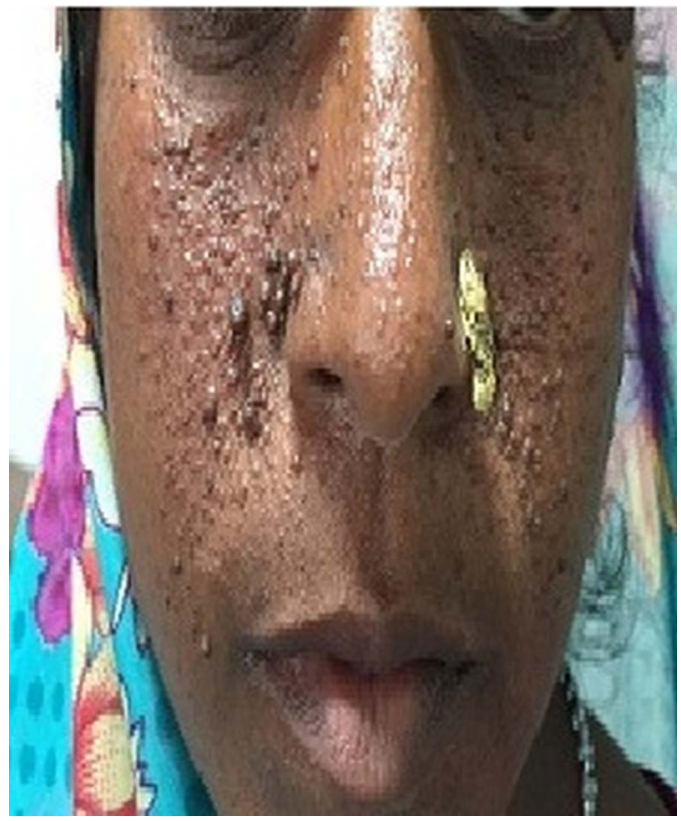

Figure 1 Multiple papules (adenoma sebaceum) over the patient's face.

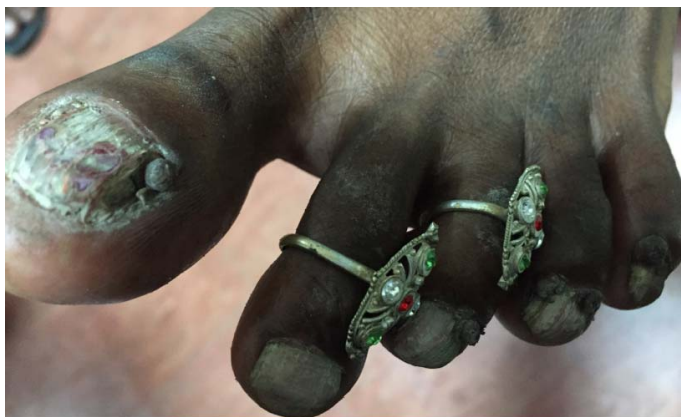

Figure 2 Periungual fibroma involving all the toes.
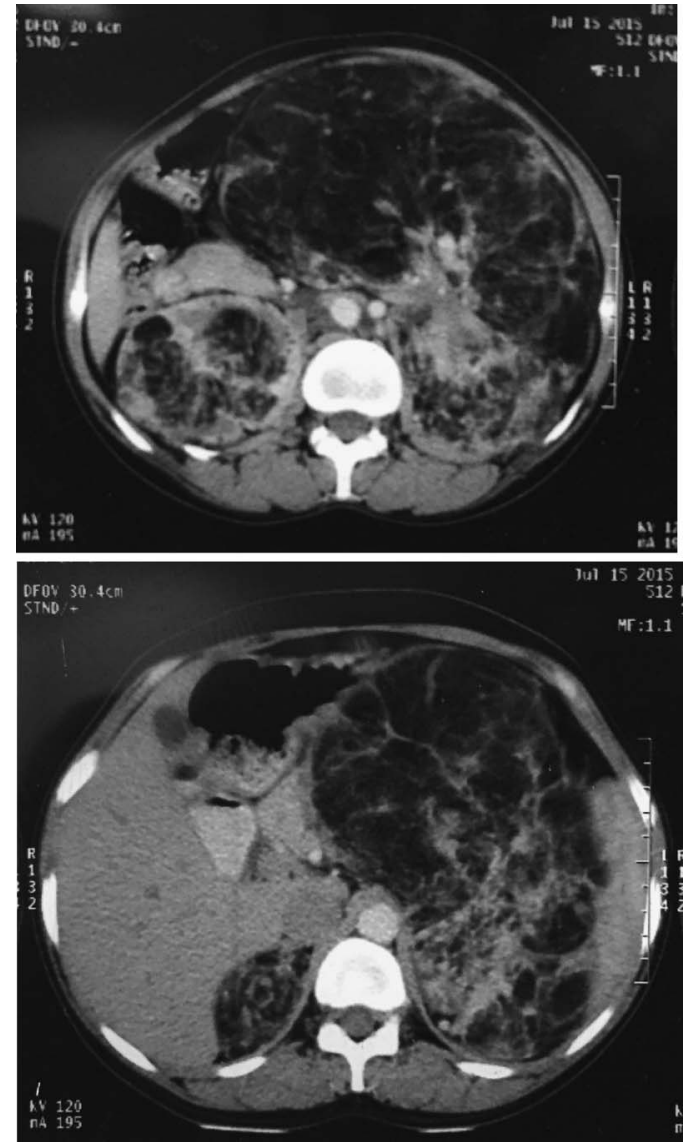

Figure $3 \mathrm{CT}$ of the abdomen suggesting large bilateral angiomyolipoma of the kidney.

of 1 in 6000 to 1 in $10000 .^{1}$ In these patients, the typical triad of epilepsy, low intelligence and adenoma sebaceum are found, as in our case. Renal angiomyolipomas are found in $50-80 \%$ of tuberous sclerosis patients and are usually bilateral with a high female preponderance suggesting hormonal influence. ${ }^{2}$ There are certain major and minor criteria defined for establishing the diagnosis, in our case, three major criteria-renal angiomyolipoma, adenoma sebaceum and periungual fibroma involving all the toes-were found. ${ }^{1}$ Renal

\section{Learning points}

- Tuberous sclerosis can present late.

- Diagnosis can be established by proper history-taking and examination.

- Continuous monitoring is a must to decrease mortality. 


\section{Images in...}

angiomyolipoma can increase in size, leading to perirenal haemorrhage. ${ }^{3}$ Patients may develop renal insufficiency as well. Similarly, other organs can have manifestations such as cerebral tumours and cardiac rhabdomyomas, although in our case none were present. However, patients need regular follow-up to decrease the mortality.

Competing interests None declared.

Patient consent Obtained.
Provenance and peer review Not commissioned; externally peer reviewed.

\section{REFERENCES}

1 Azim A, Rajkumar G. Renal angiomyolipomas in tuberous sclerosis-rare but potentially life-threatening lesions. BMJ Case Rep 2012;14:2012.

2 Nelson CP, Sanda MG. Contemporary diagnosis and management of renal angiomyolipoma. J Urol 2002;168:1315-25.

3 O'Callaghan FJ, Noakes MJ, Martyn CN, et al. An epidemiological study of renal pathology in tuberous sclerosis complex. BJU Int 2004;94:853-7.

Copyright 2016 BMJ Publishing Group. All rights reserved. For permission to reuse any of this content visit http://group.bmj.com/group/rights-licensing/permissions.

BMJ Case Report Fellows may re-use this article for personal use and teaching without any further permission.

Become a Fellow of BMJ Case Reports today and you can:

- Submit as many cases as you like

- Enjoy fast sympathetic peer review and rapid publication of accepted articles

- Access all the published articles

- Re-use any of the published material for personal use and teaching without further permission

For information on Institutional Fellowships contact consortiasales@bmjgroup.com

Visit casereports.bmj.com for more articles like this and to become a Fellow 